\title{
Comparative Analysis of Neural Mobilization and Rhythmic Stabilization in Range of Motion and Hip Pain.
}

\author{
Samyla Maria Araújo Ponte', Leydnaya Maria Souza², Bruno Cunha da Costa², Guilherme Pertinni de Morais Gouveia²
}

\begin{abstract}
Background: The hip is a structure of the human body in which occurs the junction of bone, articular, muscular and ligament structures. It is in the coxofemoral joint and has the function of supporting the whole-body weight, being one of the main joints responsible for ambulation. Objectives: To analyze the comparison of neural mobilization and rhythmic stabilization techniques in range of motion (ROM) and hip pain. Methods: The sample was composed by 20 patients, with mean age of $54 \pm 6$ years, were divided into two groups of 10 patients: the patients who received the neural mobilization technique (G1) and the patients who received the rhythmic stabilization technique (G2). Results: The mean age of each group was $56 \pm 6$ years (G1) and $52 \pm 6$ years (G2). Among the evaluated, 12 (60\%) were female, 14 (70\%) were married, predominating the profession of housewife (35\%). The great majority of the participants (95\%) presented pain to the active movement, mainly to the movements of hip flexion and abduction. Regarding passive mobilization, $70 \%$ referred pains, predominating to the movements of hip external rotation and abduction. Conclusion: It was concluded that the neural mobilization and rhythmic stabilization techniques had satisfactory results in relation to ROM and pain in the hip region, but rhythmic stabilization had a greater gain of ROM and decrease of pain.
\end{abstract}

Keywords: Hip; Neural Mobilization; Rhythmic Stabilization; Range of Motion.

\section{INTRODUCTION}

The hip is a structure of the human body in which occurs the junction of bone, articular, muscular and ligament structures. It is in the coxofemoral joint (hip joint) that consists of the head of the femur and the acetabulum and has the function of supporting the whole-body weight and allowing movements of lower limbs, being one of the main joints responsible for ambulation ${ }^{(1)}$. According to Saviatto ${ }^{(2)}$ the hip is composed of five ligaments: ischiofemoral, ligamentum teres, iliofemoral, pubofemoral and transverse acetabular, all have the purpose of stabilizing the hip, distribute loads during walk, as well as facilitating mobility. As Dangelo and Fattini ${ }^{(3)}$ reported, the hip joint is a synovial, spheroid and triaxial type, located between the lower limbs and the trunk, where the femoral head articulates with the hip bones, fitting into the acetabulum through the acetabular and ligamentum teres that maintains it coapted to the pelvic bone, thus generating better joint stability. In addition to so many properties, this joint allows movements in the sagittal, coronal and transverse planes, such as flexion-extension, internal and external rotation, and abduction and adduction. Regarding the degree of freedom, range of motion (ROM) of the hip joint varies in flexion from 0 을 to $125 \circ$, extension from 0 은 to 10 , abduction from 0 을 to 45 을 and adduction from 0 으 to 10 . In addition to these, there are movements that occur in the transverse plane and longitudinal axis, which are rotational movements around the axis itself, called internal (medial) and external (lateral) rotation. And for medial rotation the degree varies from $0^{\circ}$ to $40^{\circ}$, while for lateral from $0^{\circ}$ to $60^{\circ}(4,5)$. Thus, the range of motion is influenced by elastic and plastic properties that are present in the connective tissue constituting the muscular tissue, as well as the nervous system ${ }^{(6)}$. According to Teixeira $^{(7)}$ the mobilization of the nervous system is a technique that aims to return and facilitate movement, the elasticity of the nervous system and consequently increasing the range of motion. Therefore, neural mobilization aims to normalize both the mechanical and physiological function of the entire nervous system, even those receiving its innervation, since it coordinates muscular function ${ }^{(8)}$.

As Butler ${ }^{(9)}$, Krosshaug et al. ${ }^{(10)}$ and Williams et al. ${ }^{(11)}$ reported, the contraction of antagonistic muscles is essential for dynamic joint stability, being a direct relation between the level of muscle contraction and dynamic stiffness. Rhythmic stabilization is a technique of proprioceptive neuromuscular facilitation that aims to promote joint stabilization, as well as

\footnotetext{
Corresponding Author: Guilherme Pertinni de Morais Gouveia. Address: Av. São Sebastião, 2819 Bairro: Reis Velloso, CEP 64.202 - 020, Parnaíba (PI), Brazil. Phone number: 005586 99802-7449; E-mail: gpfatufpi@gmail.com

2 Universidade Federal do Piauí - UFPI - Parnaíba (PI), Brazil

Full list of author information is available at the end of the article.
}

Financial support: nothing to declare.

Submission date 18 July 2018; Acceptance date 20 October 2018; Publication date 02 August 2019 
analgesia of the target structure, an alternating contraction of agonist and antagonistic muscles, benefiting from the mechanism of reciprocal innervation (Sherrington principle), and reducing neuromuscular activity to a minimum level(12). Therefore, this study is justified based on the assumption that almost all individuals present or have already presented a decrease in hip amplitude, due to the large number of people complaining of pain, disability or simple discomfort in this joint. As well as the scarcity of articles on the efficacy of neural mobilization and rhythmic stabilization techniques on the hip, and the fact that these techniques are easy to perform and inexpensive. The professional physiotherapist must be competent both in relation to the humanization and associated knowledge of pathology, having not only a conservative treatment, but a treatment with new techniques. The knowledge produced should benefit physiotherapists as it will provide information to support a better performance in hip rehabilitation, as well as an effective improvement in patients with decreased range of motion and hip pain. The present study aimed to analyze the effect of neural mobilization and rhythmic stabilization techniques on ROM and hip pain.

\section{METHODS}

This is an interventionist, descriptive and analytical study, with a quantitative approach. The research was conducted in the period from November to December 2012, at the Clinic School of Physiotherapy (INTA), for presenting an environment equipped and appropriate for the execution of the technique. The study included patients from the Physiotherapy Clinic of the Faculties INTA, with ages ranging from 40 to 70 years, and were divided into two groups of 10 patients: the patients who received the neural mobilization technique (G1) and the patients who received the rhythmic stabilization technique (G2). The sample of this study was of the simple non-probabilistic random type using computerized technology, in which the names of the participants were arranged in the database and requested names needed to compose the sample. As selection criteria, the following aspects were respected: age, hip pain and range of motion. In order to select the subjects was used an anamnesis form. It was included in the study patients who: were referred for evaluation in the Physiotherapy Clinic of the faculties INTA with diagnosis of hip disorders, altered hip range, pain in the studied region, independent of gender, and agreed to participate in the study by signing the informed consent form. The present study had as exclusion criterion the patients who: gave up participating in the research; presented neurological deficit as attention, anxiety and concentration disorder; cannot execute the requested by the researcher; as well as presented stroke, Parkinson's, among others. The instruments used for data collection were assessment sheet prepared by the evaluator, Carci ${ }^{\circledR}$ goniometer (Carci Ind Com Ap Cir Ort, São Paulo, Brazil) and stretcher. The selection of the questionnaires to evaluate the degree of functionality and pain of the research subjects was based on the need to obtain reliability and validity in this evaluation. For that, four determinants were followed: first, the questionnaire should be easy to execute; second, to cover questions directed to the objective of the research; third, short time of accomplishment avoiding the fatigue of the target population; fourth, simple application mode. In order to evaluate the intensity of the pain, and to analyze if the treatment is being effective was used the Visual Analog Scale (VAS). It is an important instrument to verify the evolution of the patient during the treatment, being able to also analyze if the treatment is presenting better results, as well as if there is some deficiency in the treatment, according to the degree of improvement or worsening of the pain. The VAS can be used at the beginning and end of each attendance, recording the result always in the evolution. In order to use the VAS, the attendant should question the patient about his degree of pain, with 0 meaning total absence of pain and 10 the maximum level of pain tolerable by the patient. Goniometry is a method used to evaluate the range of motion in physiotherapeutic practice and is a low-cost, easy-tomeasure instrument. It has two arms, one being the fixed rod, which remains beside the immobile structure and the other is the movable rod, which accompanies the movement. It also has an axis or pivot, which will be on a fixed or central point to the joint to be evaluated ${ }^{(13)}$. The Straight Leg Raise (SLR) test is performed with the patient in the supine position, the cervical spine is positioned in maintained flexion, and then elevates the focused lower limb in hip flexion up to the tolerance limit of the subject. The purpose of this test is to generally stress the nerve chain at medullary level, and consequently covering the sciatic nerve ${ }^{(9,14)}$.

At the beginning, it was carried out an explanation about the research, concomitantly the invitation to participate and the reading/signing of the Informed Consent Form. After that, the subject was instructed about the tests and techniques to be performed and its importance. The protocol was divided into three stages, the first and third with evaluation and the second treatment-related. Regarding the assessment phases, at first it was verified the hip ROM. The patients were then divided into two groups of 10 patients, the first being the $\mathrm{G} 1$ group of patients who received the neural mobilization technique and $\mathrm{G} 2$ the group that received the rhythmic stabilization technique. The technique of neural mobilization was applied with the patient remaining in the supine position with the cervical spine in flexion and the affected lower limb elevated, and the therapist was positioned next to the affected limb of the patient, with the contralateral member flexed, being performed three series of thirty repetitions.

The rhythmic stabilization technique was applied with the patient in lateral decubitus position in their range of motion achieved by each diagonal, with a maximal isometric contraction with manual resistance offered by the examiner at the end of the amplitude in alternating contractions of agonist and antagonist muscles, and performed in three sets 
of six contractions. The techniques were performed in only three visits, once a week with a duration of 30 minutes per patient. It is emphasized that before and after each technique was made an evaluation composed by the evaluation form (goniometry and patient data). Then the VAS was applied, in which the intensity of the pain was evaluated in a parameter from 0 to 10 , classified as intense, moderate and painless. Finally, the hip range of motion was evaluated through the goniometer.

> Flexion - Patient in the supine position performed a hip flexion with flexed knee, with the axis of the goniometer on the greater trochanter, fixed rod on the mid axillary line and movable rod on the lateral side of the thigh, normal degree from $0^{\circ}$ to $125^{\circ}$.

> Extension - Patient in ventral decubitus performed elevation with leg extended, with the axis of the goniometer on the greater trochanter, fixed rod on the mid axillary line and movable rod on the lateral side of the thigh, normal degree from $0^{\circ}$ to $10^{\circ}$.

>Abduction - Patient in dorsal decubitus performed abduction from midline to lateral line, with the axis of the goniometer on the hip joint, fixed rod between the iliac spines and the movable rod on the anterior thigh region, normal degree from $0^{\circ}$ to $45^{\circ}$.

- Adduction - Patient in dorsal decubitus performed the return, from lateral line to midline, with the axis of the goniometer on the hip joint, fixed rod between the iliac spines and the movable rod on the anterior thigh region, normal degree from $0^{\circ}$ to $10^{\circ}$.

> Internal rotation - Patient was positioned with knee and hip flexed, performing an internal rotation of the knee, with the axis of the goniometer on the anterior face of the patella and both fixed and movable rod on the anterior surface of the tibia, normal degree from $0^{\circ}$ to $45^{\circ}$.

> External rotation - Patient was positioned with knee and hip flexed, performing an external rotation of the knee, with the axis of the goniometer on the anterior face of the patella and both fixed and movable rod on the anterior surface of the tibia, normal degree from $0^{\circ}$ to $45^{\circ}$.

The data was entered into a database using the Epi Info program (version 6.04d, Centers for Disease Control and Prevention, EUA) and the data analysis was performed using the SPSS (version 18.0). The initial analysis was performed through descriptive statistics including tabulations according to the selected variables. And for the statistical analysis, it was performed: distribution of the simple frequency of variables; chi-square association tests to verify association between outcome and exploratory variables; Pearson's correlation coefficient; and Student's t-test for independent samples ${ }^{(15)}$.
For statistical significance, was considered the value of $p$ obtained less than or equal to 0.05 .

The research was carried out following the ethical principles of Resolution 196/96 of the National Health Council(16) respecting the four basic references of bioethics: autonomy, not maleficence, beneficence and justice. Data collection was initiated after survey approval by the Ethics Committee of the Universidad Vale do Acaraú, protocol no 146.003, and authorization of those responsible for the Physiotherapy Clinic of Faculties INTA and Physiotherapy Course Coordination. This research did not include any invasive technique or evaluation with sharp materials, so it did not bring any risk to patients, only benefits such as: improvement of the symptomatology, relief of pain, and increased range of motion. The results obtained are presented in tables and figures.

\section{RESULTS AND DISCUSSION}

The sample consisted of 20 patients with mean age of $54 \pm 6$ years, in which the G1: $56 \pm 6$ years and the G2: $52 \pm 6$ years. Among the evaluated, 12 (60\%) were female, $14(70 \%)$ were married, predominating the profession of housewife (35\%).

According to Lin et al. ${ }^{(17)}$ the acceptable force limit for each region of the body depends on gender, age, health status, physical constitution, among others. These are some factors that contribute to the occurrence or worsening of the pain, which has a greater incidence in females and is aggravated by the age progress.

Regarding the pain, all reported its presence, and 11 (55\%) reported it as "burning" and the others described it as "stitches". Twelve participants (60\%) complained of uninterrupted pain. As factors for pain improvement, rest (45\%), stretching (30\%) and lying down (25\%) were mentioned. Worsening factors included bipedal position and ambulation (60\%), followed by standing (20\%) and sitting (20\%). The great majority of the participants $(95 \%)$ presented pain to the active movement, mainly to the movements of hip flexion and abduction. Regarding passive mobilization, $70 \%$ reported pain, predominantly to hip external rotation and abduction movements.

According to the analyzed data of the sample it is possible to visualize that the ambulation and the biped position are the main aggravating factors of the pain and that rest is the most associated factor in the attenuation of it. As well as the active movements are the main cause of local pain to the patient. Corroborating with these results, Kendall et al. ${ }^{(18)}$ states that the reasons for the occurrence of active movement pains may be related to the interfering pelvic and hip joint movements. The movements of the pelvic girdle show synergism, evidencing a concomitance of the movements of the pelvis, lumbar vertebrae and limbs. Although thigh movements can occur without pelvic movement, the pelvis and thigh usually move together unless there is a restriction of the activity by the trunk. 
Chart 1. Comparative analysis of pain intensity expressed by VAS before and after techniques in patients with hip pain.

\begin{tabular}{|c|c|c|}
\hline VAS - Before & VAS - After & $\mathbf{p}^{*}$ value \\
\hline $8.35 \pm 0.8$ & $4.85 \pm 1.2$ & 0.0001 \\
\hline
\end{tabular}

Note: * The paired T-test was used, statistically significant when $p<0.05$.

TABLE 1. Comparative analysis of the goniometric measurement before and after the techniques in patients with decreased hip ROM.

\begin{tabular}{cccc}
\hline Moviment & Before & After & p* $^{*}$ \\
\hline Flexion & $44.75 \pm 10.2$ & $58.5 \pm 12.7$ & 0.001 \\
Internal Rotation & $23.5 \pm 4.9$ & $28.5 \pm 7.5$ & 0.001 \\
External Rotation & $27 \pm 8$ & $31.25 \pm 5.6$ & 0.001 \\
Abduction & $21.5 \pm 5.1$ & $27.75 \pm 4.4$ & 0.001 \\
\hline
\end{tabular}

Note: * The paired T-test was used, statistically significant when $\mathrm{p}<0.05$.

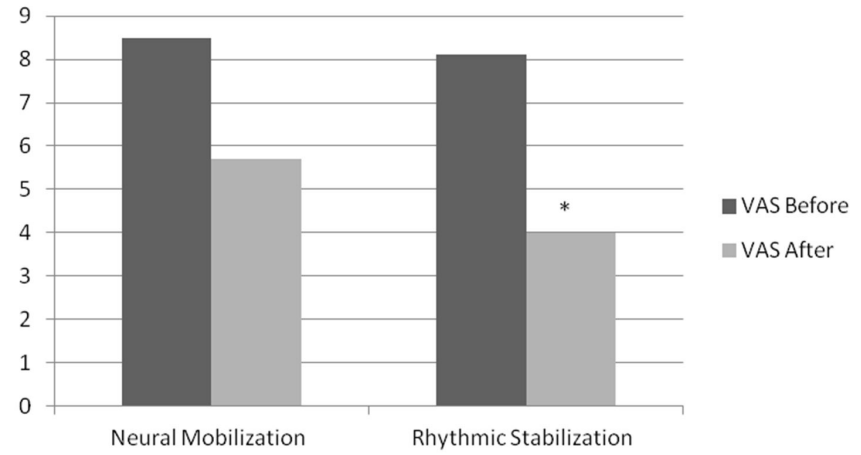

FIGURE 1. Before and after comparative analysis between techniques and pain intensity (VAS) in patients with hip pain. Note: There was a statistically significant difference at $* p=0.000$, using the t test for independent samples.
When comparing the intensity of pain expressed by the VAS before and after both treatments through the Student's T test, there was a statistically significant difference $(p<0.01)$, as shown in chart 1 . The result obtained when comparing the difference between the techniques, is shown in the figure 1 .

The results obtained in the study regarding the evaluation of visual analogue scale (VAS) evaluated the beginning and at the end of treatment showed that the two techniques were satisfactory according to the pain level of patients, but the rhythmic stabilization obtained a more efficient result in the treatment of the decrease of pain in relation to the neural mobilization. According to Costoso et al. ${ }^{(19)}$ the proprioceptive neuromuscular facilitation is based on therapeutic exercises using various facilitating mechanisms, with the purpose of promoting and/or improving muscle contraction, coordination, balance and relaxation.

When comparing the hip range of motion before and after the two techniques, using the Student's t-test, a statistically significant difference was obtained for most movements, pointing to satisfactory result of both techniques, as detailed in the table 1.

When there is limitation in range of motion, muscles that are already shortened become more and more shortened. This tendency is favored by the aging process that reduces the hydrophilic capacity causing greater rigidity of the collagenous tissue ${ }^{(20)}$.

When comparing the difference between the techniques, through the Student's t-test, a statistically significant difference was obtained only for the flexion movement, as shown in the figure 2 .

According to the results obtained, the neural mobilization and rhythmic stabilization techniques have shown satisfactory results in relation to ROM increase in the flexion, abduction, internal-external rotation movement, since these two

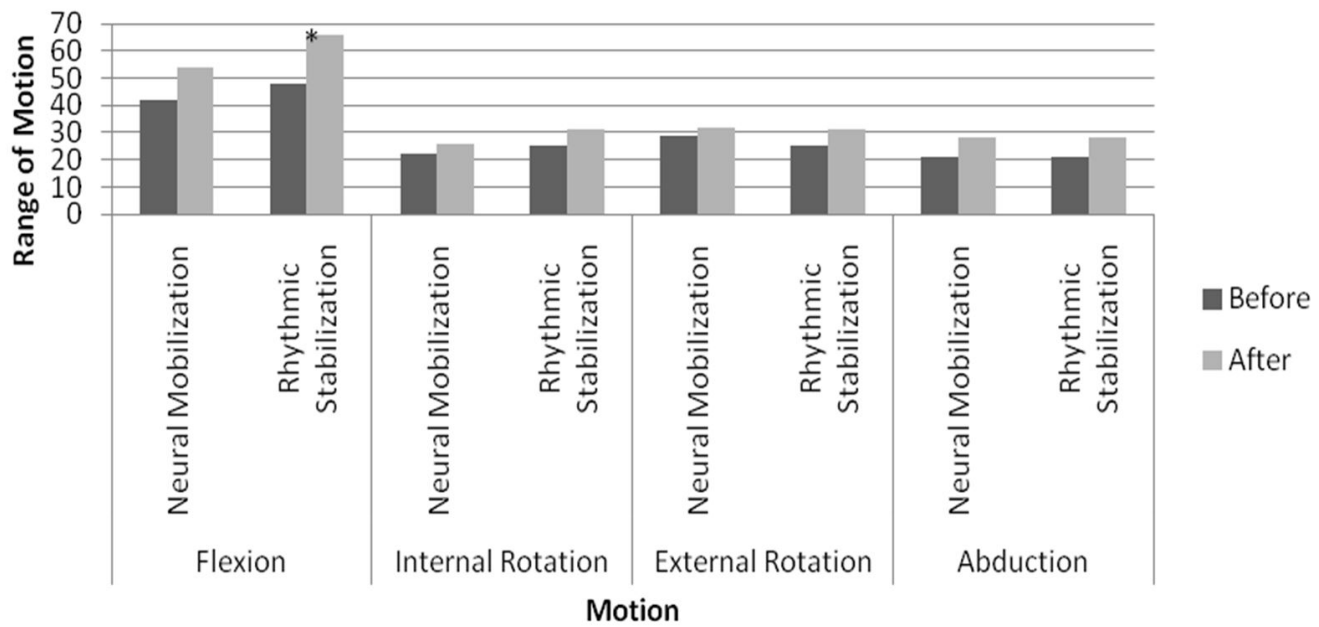

FIGURE 2. Before and after comparative analysis between techniques and range of motion in patients with decreased hip ROM. Note: There was no statistically significant difference at $* p=0.05$, using the t test for independent samples. 
techniques are aimed at increasing the movement. Regarding the rhythmic stabilization technique, there was a greater gain of ROM in the flexion and internal rotation movements proving to be more effective than the neural mobilization technique. Durigon ${ }^{(21)}$ states that the rhythmic stabilization is a technique that aims not only to have an increase in range of motion but also in the balance of forces offered by muscle synergism and joint stability.

Whereas in the external rotation and abduction movements both techniques were effective, obtaining the same results of increase of ROM. According to Domingues ${ }^{(22)}$ movements that are generated in each part of the body are transmitted to another region through tensions, however, the mobilization of the nervous system has as a proposal to change the neurodynamic. The neural mobilization technique is necessary if there is impairment in movement, elasticity, conduction, axoplasmic flow, i.e., in the physiology/mechanical function of the nervous system, and other dysfunctions may occur in the nervous system or in the musculoskeletal structures receiving innervation $^{(23)}$.

Smaniotto ${ }^{(24)}$ verified the influence of neural mobilization in the SLR position, assessing the increase of ROM in hip flexion in 10 subjects (female, sedentary and neurologically asymptomatic). It was obtained mean increase of $22.5 \div$ (7ㅇ-34을 in the ROM in hip flexion, concluding that this technique was effective in the treatment of decreased range of motion of hip flexion.

There are few articles related to the theme in analyzing the efficacy of neural mobilization and rhythmic stabilization techniques.

\section{CONCLUSION}

The participants of this study were mostly female, with mean age of 54 years, all presenting ROM decrease and hip pain. Therefore, after the analysis of the results obtained, it can be concluded that both neural mobilization and rhythmic stabilization were satisfactory in the treatment of pain reduction and in the hip range of motion, since these movements allow the nervous extensibility and elasticity to be maintained and also because they present a good therapeutic response in the regression of painful symptoms and functional incapacity. Based on the results, it was possible to verify, through the comparison of the two techniques, that there is greater efficacy of the rhythmic stabilization both in the increase of ROM and the decrease of pain in the hip in relation to the neural mobilization. It was observed that all participants in the rhythmic stabilization group showed improvement in joint stability, pain reduction and amplitude increase. It is suggested that studies be developed using a comparison between the two techniques for new scientific evidence. In view of the results, it can be concluded that the two allied techniques are a great treatment protocol to decrease pain and increase ROM.

\section{AUTHOR'S CONTRIBUTIONS}

SMAP, LMS, BCC and GPMG elaborated the design of the study, carried out the collection, statistical analysis and wrote the article.

\section{CONFLICT OF INTEREST}

Nothing to declare.

\section{AUTHORS DETAILS}

${ }^{1}$ Centro Universitário UNINTA - UNINTA, Sobral (CE) - Brazil

\section{REFERENCES}

1. Moraes CN. Efeito do método dos anéis do bad ragaz na reabilitação de pacientes submetidos à artroplastia total de quadril [monografia]. Tubarão: Universidade do Sul de Santa Catarina-USC. 2005.

2. Saviatto JM. Hidroterapia como método de reabilitação de pacientes submetidos à artroplastia total de quadril [monografia]. Tubarão: Universidade do Sul de Santa Catarina. 2006.

3. Dângelo JG, Fattini CA. Anatomia básica dos sistemas orgânicos: com a descrição dos ossos, junturas, músculos, vasos e nervos. São Paulo: Atheneu. 2005.

4. Kapandji Al. Fisiologia articular: esquemas comentados de mecânica humana. Rio de Janeiro: Guanabara. 2008.

5. Lee D. A cintura pélvica: uma abordagem para o exame e o tratamento da região lombar, pélvica e do quadril: 2001.

6. James RA, Gary LH, Kevin EW. Reabilitação Física das Lesões Desportivas. Rio de Janeiro: Guanabara Koogan: 2000.

7. Junior HFO, Teixeira AH. Mobilização do sistema nervoso: avaliação e tratamento. Rev Fisioter. Mov. 2007; 20(3).

8. Santos VR. A influência da mobilização do sistema nervoso na câimbra do escrivão. Rev Ter Man. 2004; 2(8): 166-171.

9. Butler DS. Mobilização do Sistema Nervoso. São Paulo: Manole. 2003.

10. Krosshaug T, Nakamae A, Boden BP, Engebretsen L, Smith G, Slauterbeck JR et al. Mechanisms of anterior cruciate ligament injury in basketball: video analysis of 39 cases. Am J Sports Med. 2007; 35(3): 359-367.

11. Williams GN, Chmielewski T, Rudolph K, Buchanan TS, snyder-mackler L. Dynamic knee stability: current theory and implications for clinicians and scientists. J Orthop Sports Phys Ther. 2001; 31(10): 546-556.

12. Bello M. Aplicação da técnica de estabilização rítmica em membros inferiores para prevenção de lesões musculoesqueléticas em atletas de futsal [dissertação]. São Paulo: Universidade São Judas Tadeu-USJT; 2005.

13. Venturini C, André A, Aguilar BP, Giacomelli B. Confiabilidade de dois métodos de avaliação da amplitude de movimento ativa de dorsiflexão do tornozelo em indivíduos saudáveis. Ver Acta Fisiatr. 2006; 13(1): 39-43.

14. Makofsky HW. Coluna Vertebral - Terapia Manual. Rio de Janeiro: Guanabara Koogan. 2006.

15. Pagano M, Gauvrea UK. Princípios de bioestatística. Tradução da 2a edição Norte-americana. São Paulo: Thomson Learning. 2006.

16. BRASIL. Resolução CNS no 196, de 10 de outubro de 1996. Aprova diretrizes e normas regulamentadoras de pesquisa envolvendo seres humanos. Diário Oficial da União, Brasília, DF. 1996 201(1): 210-82.

17. Yeng LT, Teixeira MJ, Romano MA, Picarelli H, Settimi MM, Greve JMA. Distúrbios ósteo-musculares relacionados ao trabalho. Rev. Med. 2001; 80(2):422-42.

18. Kendall FP, Mccreary EK, Provance PG. Provas de comprimento muscular e exercícios de alongamento. In: Músculos: provas e funções. São Paulo: Manole. 2005: 30-56. 
19. Costoso AIT, López JAB, Morales AF, Molina MIL. Fisioterapia neurológica - El método de kabat y la lesión medular espinal. Fisioterapia. 2003; 25: 2-11.

20. Archour Junior A. Bases para Exercícios de Alongamento. 2006; (2). Bases para exercícios de alongamento relacionado com a saúde e no desempenho atlético. Londrina: Midiograf, 1996.

21. Durigon OFS. Alongamento muscular. Rev. Fisio Univ. 2006;2(2):72-200.
22. Domingues CA, Santos CF. Avaliação pré e pós-mobilização neural para ganho de ADM em flexão do quadril por meio do alongamento dos isquiotibiais. Rev Conscientiae Saúde. 2008; 7(4): 487-495.

23. Salgado ASI. Coluna Vertebral-Terapia Manual. Londrina: Guanabara. 2004.

24. Smaniotto ICG, Fonteque MA. A influência da mobilização do sistema nervoso na amplitude de movimento da flexão do quadril. Rev Ter Man. 2004;2(42):154-7. 